Original research article

\title{
Postoperative pain management - knowledge and experiences of general nurses with a multicultural background
}

\author{
Denisa Porter ${ }^{1,2}$ *, Petra Búřilová ${ }^{3}$, Andrea Pokorná ${ }^{3}$ \\ ${ }^{1}$ University of Ostrava, Faculty of Medicine, Department of Nursing and Midwifery, Ostrava, Czech Republic \\ ${ }^{2}$ King Abdulaziz Medical City, National Guard Health Affairs, Post Anaesthesia Care Unit, Riyadh, Saudi Arabia \\ ${ }^{3}$ Masaryk University, Faculty of Medicine, Department of Nursing and Midwifery, Brno, Czech Republic
}

\begin{abstract}
Aim: We evaluated the knowledge and experience of general nurses, across multicultural backgrounds, on managing postoperative pain in one healthcare facility in the Kingdom of Saudi Arabia.

Methods: Online cross-sectional questionnaire survey. The data was analysed using the STATA 15 programme at significance level $\alpha=0.05$. Results: In total, 473 general nurses were involved in the survey across 16 different nationalities (average age 35.7 years, $92.4 \%$ female). The use of pain scales differs according to the type of department $(p=0.000)$. The numeric pain scale was most commonly used in the standard surgical department and the FLACC (Face, Legs, Activity, Cry, Consolability) scale in the intensive care units. The type of nonpharmacological treatment method differs according to the type of department $(p<0.05)$. The application of warm compression is the most commonly used treatment in the surgical department, while psychosocial support was declared most often in day care surgery units. Conclusions: The results showed inconsistencies in the management of postoperative pain. Different scales are used to assess pain and different procedures of non-pharmacological therapy are used. It is appropriate to establish uniform guidelines and to regularly inform general nurses about new trends in the treatment of postoperative pain, based on international standards.
\end{abstract}

Keywords: Adult; General nurses; Inpatients; Non-pharmacological treatment; Pain scales; Postoperative pain

\section{Introduction}

Postoperative pain may have a significant effect on the patient's recovery. Understanding patients' attitudes to and concerns about the postoperative pain is important for both the non-medical and medical staff, who may then identify the appropriate manner of providing effective postoperative pain treatment (Apfelbaum et al., 2003). Knowledge of postoperative pain treatment and care in patients is an inseparable part of healthcare. Postoperative care requires sufficient attention and the training of the entire healthcare staff. Postoperative pain causes patients' worries and anxiety related to both the operation itself and to the idea of suffering unbearable pain thereafter. Each patient has a right to appropriate treatment and pain management, especially in acute states, therefore the medical and nursing staff must provide comfort in the postoperative period with an appropriate pain treatment (Ireland and Lalkhen, 2019). The acute pain is brought about by an identifiable stimulus and disappears when the tissue damage is healed. The acute pain often has an obvious cause after traumas, surgical procedures or at the onset of a pathological pro- cess. Managing the postoperative pain markedly reduces the patients' suffering and results in an earlier mobilization of patients after surgery, shortening the length of stay in hospital, and also leading to increased patient satisfaction and comfort (Beyaz et al., 2011; Gupta et al., 2010).

The definition of acute pain has plenty of national and international versions. Tighe et al. (2015) describe how, according to Gale's Encyclopedia and Senega's Medical Dictionary, acute pain is in most cases temporary and results from a specific unfavourable situation under the influence of chemical, temperature or mechanical stimuli, which include surgical operation, disease, injury or infection.

According to Tieghe et al. (2015) IASP, the experience with acute pain includes the following significant characteristics: a stimulating event, sudden onset, temporal limitation, and the potential of developing into a pathological condition.

Authors of experimental studies have observed increased levels of cortisol, catecholamine and glucagon, and a subsequent decrease in the insulin sensitivity. The creation of anti-inflammatory cytokines as a result of pain and trauma contributes to pathophysiological reactions that prevent the patient's recovery (Ireland and Lalkhen, 2019).

\footnotetext{
* Corresponding author: Denisa Porter (Macková), University of Ostrava, Faculty of Medicine, Department of Nursing and Midwifery, Syllabova 19, 70300 Ostrava-Vítkovice, Czech Republic; e-mail: denisa.mackova@seznam.cz http://doi.org/10.32725/kont.2021.028 
Healthcare professionals need to master both pharmacological and non-pharmacological procedures used for treating the postoperative pain, which may provide patients with relief from the pain (Jensen et al., 2013; Ng and Cashman, 2018).

The acute pain can be described as a response to tissue damage that causes postoperative pain and stress in patients and results in changes in the human organism by influencing the cardiovascular system, the gastrointestinal system (hereinafter the GIT), the excretory system, the neuroendocrine system, the immune system, the neurovascular system, etc. An ineffectively treated postoperative pain that continues for a long time may result in sleeping disorders, mental activity disorders, or feelings of anxiety (Beyaz et al., 2011).

The author of the present article gained the motivation to perform this study when she was attaining her professional experience in treating postoperative pain in the Kingdom of Saudi Arabia (hereinafter the KSA). In the KSA, general nurses of multiple cultures are employed, contributing different experiences, knowledge, and backgrounds to the postoperative pain treatment. Due to the considerable multicultural dissimilarity, it was interesting to find out what differences exist in postoperative pain treatment in the KSA.

The aim was to evaluate the knowledge and experience of general nurses with a multicultural background in managing postoperative pain in early postoperative period in the KSA.

\section{Materials and methods}

\section{Design}

A cross-sectional questionnaire survey was performed among a selected sample of general nurses with a multicultural background working at inpatient surgical departments in KSA.

\section{Tools used for data collection/participants}

We did not find any standardized questionnaire for evaluating the knowledge of nurses in the management of postoperative care in the literature search (Mackova and Pokorna, 2020). Thus we have created a non-standardized questionnaire with structured questions as a basis for the data collection (consisting of 34 items) based on previously identified studies (Mackova and Pokorna, 2020). The questionnaire was created according to the aims of the study, in which the authors were to find out what knowledge general nurses had in postoperative pain management, and the perceived autonomy level of general nurses with postoperative pain management. The questionnaire was developed based on the available clinical guidelines that focused on postoperative pain management. We developed a questionnaire to assess deviations from the best practices during the postoperative pain management and to identify related common nursing interventions and care habits. For content validity, both questionnaire methodologists and postoperative pain management experts confirmed the questionnaire. This included senior researchers, general nurses, enrolled nurses, heads of departments, physicians at the university department and hospital, as well as researchers with considerable experience in questionnaire design. Instructors from the local operating theaters from KSA also double-checked that the questions were in accordance with guidelines. Criterion validity was applied as we followed the guidelines. The questionnaire was developed and approved in collaboration with one senior researcher (AP), one junior researcher (DP), two nursing content experts, clinical nurses working in the postoperative units $(\mathrm{RH}, \mathrm{LB})$, and one senior consultant - anesthesiologist physician ( $\mathrm{MH})$. To establish face validity, a focus group with four enrolled nurses discussed the questionnaire items on two occasions. They had considerable experience of postoperative pain management in a hospital setting. In KSA, it is enrolled nurses who most often perform postoperative pain management, therefore these nurses participated in a focus group. Their role was to identify any items that could possibly be misinterpreted. All of them gave their consent to participate in the study.

The questionnaire was divided into two parts. The first part includes demographic questions: gender, age, nationality, education, department at which the respondent works, and the length of professional experience. The second part consists of questions related to the knowledge of general nurses in postoperative pain management. Special attention was paid to the pain scales - tools used to evaluate the postoperative pain, possibility to collaborate with the Acute Pain Service (APS), and the usage of Patient Controlled Analgesia (PCA). We also included questions about how general nurses perceive their autonomy in treating the postoperative pain, and whether they can interfere and participate in the postoperative pain treatment. The questionnaire includes, among other items, the most common methods of non-pharmacological pain treatment, the most frequently used medicine for the postoperative pain treatment, and questions related to epidural analgesia and the experience in caring for patients with PCA. We will present the selected outcomes in the results section with special focus on pain scales and non-pharmacological treatment methods.

The questionnaire was distributed in electronic form to general nurses working at surgical departments with patients in the postoperative period. The essential criterion for participation in the questionnaire survey was that the respondents are general nurses working at any surgical department (Standard surgical departments, Day care surgery unit, Post Anaesthesia Care Unit, Surgical Intensive Care Units - ICUs) and are caring for patients in the postoperative period. Other criteria included the following: minimum of 20 years of age, at least 2 years of professional experience, at least the minimum education completed that meets the statutory requirements for acquiring the professional competence to perform the general nurse's profession in the given state, and finally, multicultural nationality.

\section{Data collection}

The questionnaire was distributed to 550 general nurses via workplace email addresses. In total, 77 (14\%) questionnaires were excluded due to incompleteness or because the respondents failed to meet the inclusion criteria. The final number of questionnaires used for the statistical analysis was 473 (response rate $86 \%$ ). We followed the STROBE checklist guidelines.

\section{Study variables and measures}

The statistical analysis was performed through STATA 15. The normality of variables was evaluated by means of visual assessment of histograms, which was adequate given the central limit theorem and the number of respondents. In category variables, we included the relative frequencies, their distribution was tested using chi-squared test. To compare the groups of continuous variables we used arithmetic means and statistical testing by means of a two-tailed t-test for an independent sample or by analysing the ANOVA range of scattering. All the tests were two-tailed; $p<0.05$ was considered statistically significant at the significance level $5 \%$ with no further alterations for multiple-tailed comparisons. 


\section{Validity and reliability}

The sample of respondents was a sufficient size $(N=473)$ to perform statistical analysis and operations. The generalizability of all results was verified through the statistical significance of p-value. No standardized questionnaire was used, but all the questions are only exploratory and it is not necessary to test and analyse their properties. The questionnaire is based on mostly descriptive categorical questions with only a few scale questions independent of each other; the measurement of questions' reliability is irrelevant for the questionnaire.

\section{Results}

\section{Analysed sample}

The demographic and identification data of the analysed sample $(N=473)$ are specified in Table 1 .

The majority of the respondents were women (92.4\%). The average age of the respondents was 35.7 years (min. 23 years and max. 59 years). The biggest group of respondents were general nurses with a Bachelor's degree (72.1\%). The second most common group were general nurses with a higher secondary professional education - diploma nurses (25.2\%). Only $2.5 \%$ were general nurses with a Master's degree, while $0.2 \%$

Table 1. Research sample characteristics $(N=473)$

\begin{tabular}{|c|c|c|}
\hline \multicolumn{3}{|c|}{ Demographic data } \\
\hline Gender & $N$ & $\%$ \\
\hline Female & 437 & 92.4 \\
\hline Male & 36 & 7.6 \\
\hline \multicolumn{3}{|c|}{ Age } \\
\hline Average age & \multicolumn{2}{|c|}{35.68 years } \\
\hline Minimum age & \multicolumn{2}{|c|}{23 years } \\
\hline Maximum age & \multicolumn{2}{|c|}{59 years } \\
\hline \multicolumn{3}{|c|}{ Education } \\
\hline Level of education & $N$ & $\%$ \\
\hline Diploma degree & 119 & 25.16 \\
\hline Bachelor's degree (BSc.) & 341 & 72.09 \\
\hline Master's degree (MSc.) & 12 & 2.54 \\
\hline Other & 1 & 0.21 \\
\hline \multicolumn{3}{|c|}{ Occupation } \\
\hline \multicolumn{3}{|l|}{ Length of work experience } \\
\hline Average length & \multicolumn{2}{|c|}{12.35 years } \\
\hline Minimum length & \multicolumn{2}{|c|}{2 years } \\
\hline Maximum length & \multicolumn{2}{|c|}{40 years } \\
\hline Department & $N$ & $\%$ \\
\hline Surgical department & 177 & 37.42 \\
\hline Day care surgery unit & 18 & 3.81 \\
\hline Post-anaesthesia care unit & 73 & 15.43 \\
\hline Surgical ICU & 190 & 40.17 \\
\hline Other & 15 & 3.17 \\
\hline
\end{tabular}

Note: "Other education" refers to doctorate degree; "Other departments" includes medical surgical ICU step-down, Haematology transplant department, Neurosurgery ICU, Cardiac surgery ICU and Cardiac surgery department. were general nurses with "other" types of education (not specified). The average length of professional experience in the general nurses was 12.4 years. The respondents came from sixteen multicultural nationalities, see Table 2.

\begin{tabular}{lcc} 
Table 2. Nationality of the respondents $(\mathbf{N}=\mathbf{4 7 3})$ & \\
\hline Nationality & $N$ & $\%$ \\
\hline British & 6 & 1.27 \\
\hline Canadian & 1 & 0.21 \\
Czech & 10 & 2.11 \\
\hline Finnish & 3 & 0.63 \\
\hline Indian & 9 & 1.90 \\
\hline Irish & 2 & 0.42 \\
\hline Jordanian & 2 & 0.42 \\
\hline Malaysian & 145 & 30.66 \\
\hline Filipino & 234 & 49.47 \\
\hline Portuguese & 4 & 0.85 \\
\hline Puerto Rican & 1 & 0.21 \\
\hline Saudi & 26 & 5.50 \\
\hline South African & 16 & 3.38 \\
\hline South Korean & 11 & 2.33 \\
\hline Slovak & 2 & 0.42 \\
\hline Spanish & 1 & 0.21 \\
\hline
\end{tabular}

\section{Tools for postoperative pain evaluation}

Different tools (pain scales) were declared by general nurses at different departments for postoperative pain evaluation. The usage of pain scales differs according to the type of department ( $p=0.000)$, see Table 3 . The option in the "other" section includes departments such as medical and surgical ICU stepdown, Haematology transplant department, Neurosurgery ICU, Cardiac surgery ICU, and Cardiac surgery department.

\section{Non-pharmacological treatment}

The respondents chose from a wide range of non-pharmacological options, which included musical therapy, touching, application of warmth or cold compression, hydrotherapy, psycho-social support, yoga, massages or "others". The most frequently mentioned answers were emotional support, changes of position, deep breathing exercises, diversional therapy using TV, prayer and spiritual support, comforting environment, presence of family members, physiotherapy or ergotherapy.

Respondents working at all types of departments/units often mentioned the application of warmth. It is most commonly used by general nurses in standard surgical departments (54.2\%) and post-anaesthesia care units (50.7\%). We have verified statistical differences in warmth application according to the type of department $(p=0.001)$.

The most commonly mentioned postoperative pain relief method was psychosocial support. It was the method most often selected by general nurses from all types of departments: day care surgery (83.3\%), "other" departments (80.0\%), post anaesthesia care unit (76.7\%), surgical ICU (61.1\%), and standard surgical department (55.4\%). We have verified that the use of psychosocial support as a method of non-pharmacological postoperative pain relief differs according to the type of department $(p=0.004)$. 
Table 3. Type of pain scale related to the type of department $(N=473)$

\begin{tabular}{|c|c|c|c|c|c|c|c|}
\hline \multirow{2}{*}{ Department } & \multicolumn{6}{|c|}{ Type of scale \% } & \multirow{2}{*}{$p$-value ${ }^{* *}$} \\
\hline & FLACC & CRIES & NRS & VAS colour & VAS line & Facial - Wong Baker & \\
\hline Surgical department & 15.25 & 2.26 & 76.27 & 0.00 & 0.00 & 6.21 & \multirow{5}{*}{0.000} \\
\hline Day care surgery unit & 22.22 & 5.56 & 66.67 & 0.00 & 0.00 & 5.56 & \\
\hline Post anaesthesia care & 61.64 & 2.74 & 28.77 & 0.00 & 0.00 & 6.85 & \\
\hline Surgical ICU & 82.11 & 6.32 & 8.95 & 0.53 & 0.00 & 2.11 & \\
\hline${ }^{*}$ Other & 86.67 & 6.67 & 6.67 & 0.00 & 0.00 & 0.00 & \\
\hline
\end{tabular}

Note: FLACC - Face, Legs, Activity, Cry, Consolability; CRIES - Crying, Requiring oxygen, Increased vital signs, Expression, Sleeplessness;

NRS - Numeric Rating Scale; VAS - Visual Analogue Scale; * "Other departments" includes medical surgical ICU step-down, Haematology transplant department, Neurosurgery ICU, Cardiac surgery ICU and Cardiac surgery department; ** chi-square test.

We can conclude that the non-pharmacological postoperative pain relief methods differ according to the type of department and according to the type of non-pharmacological methods ( $p=0.001$ was the lowest for the application of warmth, and $p=0.875$ was the highest for hydrotherapy), see Table 4 . We did not find any differences based on the nationality of respondents.

Table 4. Non-pharmacological treatment $(N=473)$

\begin{tabular}{|c|c|c|c|c|c|c|c|c|}
\hline \multirow{2}{*}{ Department } & \multicolumn{8}{|c|}{ Non-pharmacological treatment $\%$} \\
\hline & Music & Touch & Warmth & Hydrotherapy & Psycho-therapy & Yoga & Massage & Others \\
\hline Surgical department & 3.4 & 31.1 & 54.2 & 0.6 & 55.4 & 10.2 & 23.7 & 21.5 \\
\hline Day care surgery unit & 0.0 & 38.9 & 38.9 & 0.0 & 83.3 & 11.1 & 0.0 & 27.8 \\
\hline Post anaesthesia care & 1.4 & 46.6 & 50.7 & 0.0 & 76.7 & 9.6 & 30.1 & 28.8 \\
\hline Surgical ICU & 5.3 & 46.8 & 33.2 & 1.1 & 61.1 & 2.6 & 30.5 & 31.1 \\
\hline * Other & 6.7 & 20.0 & 26.7 & 0.0 & 80.0 & 13.3 & 20.0 & 33.3 \\
\hline Chi-square & 0.491 & 0.009 & 0.001 & 0.875 & 0.004 & 0.038 & 0.048 & 0.314 \\
\hline
\end{tabular}

* Other departments" includes medical surgical ICU step-down, Haematology transplant department, Neurosurgery ICU, Cardiac surgery ICU and Cardiac surgery department.

The view of general nurses on the education provided in postoperative pain management

Another goal was to determine the views of general nurses in relation to the level of education provided (in their hospital and respective departments/units) that focused on the management of postoperative pain. In the questionnaire, the respondents were offered 5 options according to the Likert scale to answer: "In your opinion, does your workplace pay sufficient attention to educating healthcare workers in how to treat pain?" The options available were: (1) definitely yes; (2) yes; (3) not sure, difficult to assess; (4) not really; (5) definitely not. We can conclude from the results that the views of general nurses on the provided education in postoperative pain management do not differ depending on the type of department they work in $(p=0.969)$. The most frequent response was option number 1 - definitely yes (73.4\%), and the average value the respondents answered was 1.35 .

Table 5. The view of general nurses on the education provided in postoperative pain management $(N=473)$

\begin{tabular}{|c|c|c|c|c|c|c|}
\hline \multirow{2}{*}{ Department } & \multicolumn{5}{|c|}{ General nurses' view on the education provided in postoperative pain management $\%$} & \multirow{2}{*}{$p$-value* } \\
\hline & 1 & 2 & 3 & 4 & 5 & \\
\hline Surgical department & 70.6 & 25.4 & 2.3 & 1.1 & 0.6 & \\
\hline Day care surgery unit & 72.2 & 27.8 & 0.0 & 0.0 & 0.0 & \\
\hline Post anaesthesia care & 76.7 & 17.8 & 4.1 & 1.4 & 0.0 & 0.969 \\
\hline Surgical ICU & 67.4 & 29.5 & 2.1 & 0.5 & 0.5 & \\
\hline * Other & 80.0 & 20.0 & 0.0 & 0.0 & 0.0 & \\
\hline
\end{tabular}

* Other departments" includes medical surgical ICU step-down, Haematology transplant department, Neurosurgery ICU, Cardiac surgery ICU and Cardiac surgery department. 


\section{Discussion}

Through this study, we have found differences in the management of postoperative pain among general nurses with multicultural background working in the KSA. The sample of general nurses used for the statistical data processing was $(N=473)$ with 16 different nationalities. The survey has shown considerable differences in postoperative pain management between general nurses at different departments.

The results of our survey have shown that general nurses use various rating scales to evaluate postoperative pain. The FLACC scale was the most used at post-anaesthesia care units, surgical ICU's, and wards identified as "others". The results, in this case, were as expected; post-surgery patients are lethargic and sedated, and therefore we assumed that general nurses would most frequently use the FLACC scale to evaluate pain (Choueiry et al., 2020). We confirmed statistical significance among the different departments and the use of pain scales and tools for assessing the postoperative pain $(p=0.000)$. Similar assumptions applied to surgical ICUs, where patients are intubated and also under sedation. In another study (Xavier et al., 2018), which described postoperative pain evaluation by general nurses $(N=12)$, the authors agreed that general nurses used no standardized tools for postoperative pain evaluation. It was recommended that general nurses undertake additional training and education related to postoperative pain management in order to be able to implement a suitable assessment tool/pain scale (Xavier et al., 2018). In our survey, the least respondents chose the "VAS colour" scale. The "VAS line" scale was not chosen at all. The studies by Kjeldsen et al. (2016) and Rauh et al. (2013) found out that patients preferred the NRS scale over the "VAS" scales. Based on the available studies, the NRS scale seems to be a good option for measuring postoperative pain reliably and is easy to understand for the patients. Thanks to the proper evaluation of postoperative pain by using the NRS scale, patients received adequate analgesic treatment (Kjeldsen et al., 2016; Rauh et al., 2013). The nurses in our study also used NRS, mostly at standard surgical departments. Another study has declared that general nurses do not use specific pain assessment tools and that they are assessing postoperative pain by observing patients or through needs expressed by the patients (Fielding and Irwin, 2006). We can conclude that the findings of our survey are more positive because, as expected, at ICUs the FLACC scale was used, and at standard departments the NRS scale was preferred. The general nurses who participated in our study were aware of proper pain assessment tools and used them with regard to the type of department they worked in and the patient's condition.

In relation to non-pharmacological treatment methods, from the results of our study we can conclude that general nurses are aware and informed about non-pharmacological methods and they know what appropriate interventions can be used to relieve pain in patients during the postoperative period. The most frequently declared method was psychosocial support $(p=0.004)$, while the use of hydrotherapy was the least frequent ( $p=0.875)$. Yaban's study (2019), which dealt with the same subject matter as our study, describes insufficient knowledge and experience of general nurses in relation to the application of non-pharmacological methods, and generally a very low willingness to use the non-pharmacological methods to relieve postoperative pain in patients.

The education of general nurses plays a crucial and important role in postoperative pain management. The results of our study have shown this, and it has been confirmed that this matter is given sufficient attention. As we can see from the data available, general nurses most commonly declared that sufficient attention is paid to the education of general nurses in postoperative pain management at their respective healthcare facilities. When we compare our findings with international studies that have analyzed the same issue, we can conclude that general nurses still need more training in managing postoperative pain in patients (Borys el al., 2018; Fielding and Irwin, 2006; Yaban, 2019).

Another multicentre observational study, which evaluated knowledge in postoperative pain management, found that, for example, there is a problem with correct techniques and routes of administration of analgesia. The authors of the study stated that if general nurses are adequately trained they will be more confident in the proper management of postoperative pain and, if needed, they will eventually be able to provide effective first aid if a patient developed any adverse reaction as a result of intravenous (IV) drugs administration (Borys el al., 2018; Fielding and Irwin, 2006). Very similar results were declared in another study that defined the barriers which prevent proper pain management due to the inadequate training of general nurses, an imperfect "nurse-patient" relationship, the limited autonomy and authority of general nurses, and the failure of interventions, that are necessary during postoperative pain management (Rejeh et al., 2009).

The treatment provided to patients can be inadequate and not in line with international recommendations and standards (Eshete et al., 2019). In our sample, we also verified that the interventions in postoperative pain management were inconsistent with the recommended guidelines for treating actual pain, which is in accordance with another published study (Erden et al., 2017). Therefore, nurses should increase the awareness of the pain assessment records for effective pain management. In addition, the administrative staff of the hospital should support the use of standard pain assessment according to the type of care provided, considering the latest available evidence-based nursing and practice recommendations.

\section{Strengths and limitations of the study}

The main strength of the study is that it studies the hitherto insufficiently explored issue of postoperative pain management in a specific hospital that employs general nurses of multiple nationalities. A relatively limiting factor was the distribution method of the questionnaire: on the one hand the electronic form may increase the response rate, but on the other it increases the risk of respondents searching for the information; thus, the data declared may not accurately reflect the level of their actual knowledge. This risk was low however, as the majority of the questionnaire items focused on the nurses' experience rather than knowledge. As the study was completed in one selected hospital we assume that, based on the results, we can implement new and more effective strategies for postoperative pain management.

\section{Conclusions}

The study discovered deficiencies in the knowledge of general nurses in postoperative pain management. We found a discrepancy and no uniformity in the use of pain scales according to the different type of departments. This leads us to the conclusion of low general nurse competency and a lack of standardisation in this matter. On the other hand, we have found satisfactory results regarding the knowledge of general nurses 
in the selection of proper non-pharmacological methods for postoperative pain management. According to the respondents' answers, we can declare that the general nurses in our sample have sufficient knowledge, experience, and training regarding the use of various non-pharmacological methods that are used to relieve postoperative pain. Even though the respondents in our study perceived the level of education provided in postoperative pain management as sufficient (score of 1.35 on a 5 -point numerical scale), it is still necessary to continue to conduct research studies and educational programs related to postoperative pain management in order to improve the knowledge and competencies of general nurses. We are working on a similar survey among nurses in the Czech Republic as a follow-up study. We strongly believe that, in the Czech Republic, the collaboration between surgeons, anaesthesiologists and nurses is closer during postoperative pain management, and we would therefore like to compare the situation in the KSA and Czech Republic as a follow-up study.

\section{Author contributions}

Conception and design of the manuscript (DP, AP), data analysis and interpretation (DP, AP), manuscript draft (DP, AP, PB), critical revision of manuscript (DP, $\mathrm{PB}, \mathrm{AP}$ ), final approval of the manuscript (AP).

\section{Ethical aspects and conflict of interests}

The authors declare that they are not aware of any conflict of interests regarding this contribution.

\section{Acknowledgements}

The authors acknowledge the support of the King Abdulaziz Medical City, National Guard Health Affairs Hospital (KAMC NGHA), Post Anaesthesia Care Unit. King Abdulla International Medical Research Centre (KAIMRC), Riyadh, Saudi Arabia. As well as the support of the University of Ostrava, Faculty of Medicine, Department of Nursing and Midwifery in Ostrava, Czech Republic. The views expressed are those of the authors and not necessarily those of the KAMC NGHA, KAIMRC or the University of Ostrava.

\section{Funding}

The study was supported by the project: Pain Management in the Postoperative Period, Knowledge and Experience of General Nurses (Czech Republic and Kingdom of Saudi Arabia), SGS05/LF/2019-2020, Medical Faculty University of Ostrava, Czech Republic.

\title{
Léčba pooperační bolesti - znalosti a zkušenosti všeobecných sester s multikulturní přislušností
}

\begin{abstract}
Souhrn
Cíl: Zhodnotit znalosti a zkušenosti všeobecných sester s multikulturní příslušností s léčbou pooperační bolesti v konkrétním zdravotnickém zařízení v Království Saúdské Arábie.

Metodika: Online, průřezový dotazníkový průzkum. Data byla analyzována pomocí programu STATA 15 na hladině významnosti $\alpha=0.05$.

Výsledky: Do průzkumu bylo zařazeno celkem 473 všeobecných sester 16 různých národností, (průměrný věk 35,7 let, 92,4 \% ženy). Zjistili jsme, že se liší používané škály k hodnocení bolesti na různých odděleních $(p=0,000)$. Na chirurgickém oddělení je nejčastěji používaná numerická škála, na jednotkách intenzivní péče je to škála FLACC (Face, Legs, Activity, Cry, Consolability). Typ nefarmakologické léčby se liší dle typu pracoviště $(p<0,05)$. Aplikace tepla je nejčastější na standardních chirurgických odděleních a psychosociální podpora byla deklarována nejčastěji na oddělení jednodenní chirurgie.

Závěr: Z výsledků vyplynula nejednotnost v managementu pooperační bolesti. Využívány jsou odlišné škály k hodnocení bolesti i různé postupy nefarmakologické terapie. Vhodné je zavést jednotné pokyny a pravidelně informovat všeobecné sestry o nových trendech v léčbě pooperační bolesti vycházející z mezinárodních standardů.
\end{abstract}

Klíčová slova: dospělý; hospitalizovaný; nefarmakologická léčba; pooperační bolest; škály bolesti; všeobecné sestry

\section{References}

1. Apfelbaum J, Chen C, Mehta S, Gan TJ (2003). Postoperative Pain Experience: Results from a National Survey suggest postoperative pain continues to be undermanaged. Anesth Analg 97(2): 534-540. DOI: 10.1213/01. ane.0000068822.10113.9e.

2. Beyaz SG, Bayar F, Erdem AF (2011). Acute postoperative pain. J Anesth Clin Res 4(286): 1-8. DOI: 10.4172/21556148.1000286.

3. Borys M, Zyzak K, Hanych A, Domagała M, Gałkin P, Gałaszkiewicz K, et al. (2018). Survey of postoperative pain control in different types of hospitals: a multicenter observational study. BMC Anesthesiol 18(1): 83. DOI: 10.1186/ s12871-018-0551-3.

4. Choueiry J, Reszel J, Hamid JS, Wilding J, Martelli B, Harrison D (2020). Development and Pilot Evaluation of an
Educational Tool for the FLACC Pain Scale. Pain Manag Nurs 21(6): 523-529. DOI: 10.1016/j.pmn.2020.06.002.

5. Erden S, Arslan S, Deniz S, Kaya P, Gezer D (2017). A review of postoperative pain assessment records of nurses. Appl Nurs Res 38: 1-4. DOI: 10.1016/j.apnr.2017.08.003.

6. Eshete MT, Baeumler PI, Siebeck M, Tesfaye M, Haileamlak A, Michael GG, et al. (2019). Quality of postoperative pain management in Ethiopia: A prospective longitudinal study. PLoS One 14(5): e0215563. DOI: 10.1371/journal. pone.0215563.

7. Fielding R, Irwin MG (2006). The knowledge and perceptions of nurses and interns regarding acute pain and postoperative pain control. Hong Kong Med J 12(Suppl. 1): S31-34.

8. Gupta A, Kaur K, Sharma S, Goyal S, Arora S, Murthy RSR (2010). Clinical aspects of acute post-operative pain management \& its assessment. J Adv Pharm Technol Res 1(2): 97-108. 
9. Ireland CK, Lalkhen AG (2019). Postoperative Analgesia. Anaesth Int Care 20(2): 98-104. DOI: 10.1016/j. mpaic.2018.12.007.

10. Jensen MJ, Sherlin LH, Askew RL, Witkop FFG, Gianas A, Howe JD, Hakimian S (2013). Effects of non-pharmacological pain treatments on brain states. Clin Neurophysiol 124(10): 2016-2024. DOI: 10.1016/j.clinph.2013.04.009.

11. Kjeldsen HB, Klausen TW, Rosenberg J (2016). Preferred Presentation of the Visual Analog Scale for Measurement of Postoperative Pain. Pain Pract 16(8): 980-984. DOI: 10.1111/ papr.12344.

12. Mackova D, Pokorna A (2020). Management of postoperative pain. Kontakt 22(2): 96-103. DOI: 10.32725/kont.2020.018.

13. Ng L, Cashman J (2018). The management of acute pain. Med J 46(12): 780-785. DOI: 10.1016/j.mpmed.2018.09.009

14. Rauh KH, Andersen RS, Rosenberg J (2013). [Visual analogue scale for measuring post-operative pain]. Ugeskr Laeger 175(24): 1712-1716.
15. Rejeh N, Ahmadi F, Mohammadi E, Kazemnejad A, Anoosheh M (2009). Nurses' experiences and perceptions of influencing barriers to postoperative pain management. Scand J Caring Sci 23(2): 274-281. DOI: 10.1111/j.1471-6712.2008.00619.x

16. Tighe P, Buckenmaier CC, 3rd, Boezaart AP, Carr DB, Clark LL, Herring AA, et al. (2015). Acute Pain Medicine in the United States: A status report. Pain Med 16(9): 1806-1826. DOI: $10.1111 /$ pme.12760.

17. Woldehaimanot TE, Eshetie TCH, Kerie MW (2014). Postoperative Pain Management among Surgically Treated Patients in an Ethiopian Hospital. PLoS One 9(7): e102835. DOI: 10.1371/journal.pone.0102835.

18. Xavier AT, de Lima MK, Burgos TMR, De Lira MCC, Serrano SQ (2018). Evaluation of postoperative pain under the nurse's point of view. J Nurs UFPE on Line 12(9): 2436-2441. DOI: 10.5205/1981-8963-v12i9a234730p2436-2441-2018.

19. Yaban ZS (2019). Usage of Non-Pharmacologic Methods on Postoperative Pain Management by Nurses: Sample of Turkey. Int J Caring Sci 12(1): 529-541. 